\title{
Turner syndrome
}

INSERM

\section{Source}

INSERM. (1999). Orphanet: an online rare disease and orphan drug data base. Turner syndrome. ORPHA:881

Turner syndrome is a chromosomal disorder associated with the complete or partial absence of an X chromosome. 